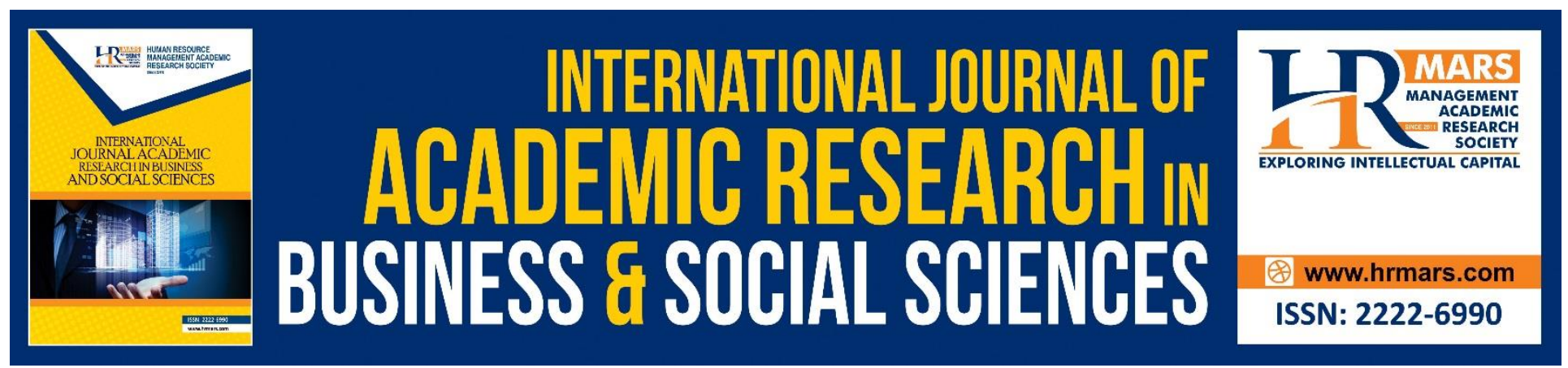

\title{
Improvement in Sarf(Morphology) Competency through Gamification at Miri National Religious Secondary School (SMKAMi)
}

Suhaila Zailani, Kaseh Abu Bakar, Nik Farhan Mustapha, Hakim Zainal, Zulkifli Nawawi \& Ezad Azraai Jamsari

To Link this Article: http://dx.doi.org/10.6007/JJARBSS/v9-i1/5472

DOI: $\quad 10.6007 /$ IJARBSS/v9-i1/5472

Received: 02 Jan 2019, Revised: 26 Jan 2019, Accepted: 11 Feb 2019

Published Online: 16 Feb 2019

In-Text Citation: (Zailani et al., 2019)

To Cite this Article: Zailani, S., Bakar, K. A., Mustapha, N. F., Zainal, H., Nawawi, Z., \& Jamsari, E. A. (2019). Improvement in Sarf (Morphology) Competency through Gamification at Miri National Religious Secondary School (SMKAMi). International Journal of Academic Research in Business and Social Sciences, 9(1), 684-697.

Copyright: (c) 2019 The Author(s)

Published by Human Resource Management Academic Research Society (www.hrmars.com)

This article is published under the Creative Commons Attribution (CC BY 4.0) license. Anyone may reproduce, distribute, translate and create derivative works of this article (for both commercial and non-commercial purposes), subject to full attribution to the original publication and authors. The full terms of this license may be seen at: http://creativecommons.org/licences/by/4.0/legalcode

Vol. 9, No. 1, 2019, Pg. 684 - 697

http://hrmars.com/index.php/pages/detail/IJARBSS

JOURNAL HOMEPAGE

Full Terms \& Conditions of access and use can be found at http://hrmars.com/index.php/pages/detail/publication-ethics 


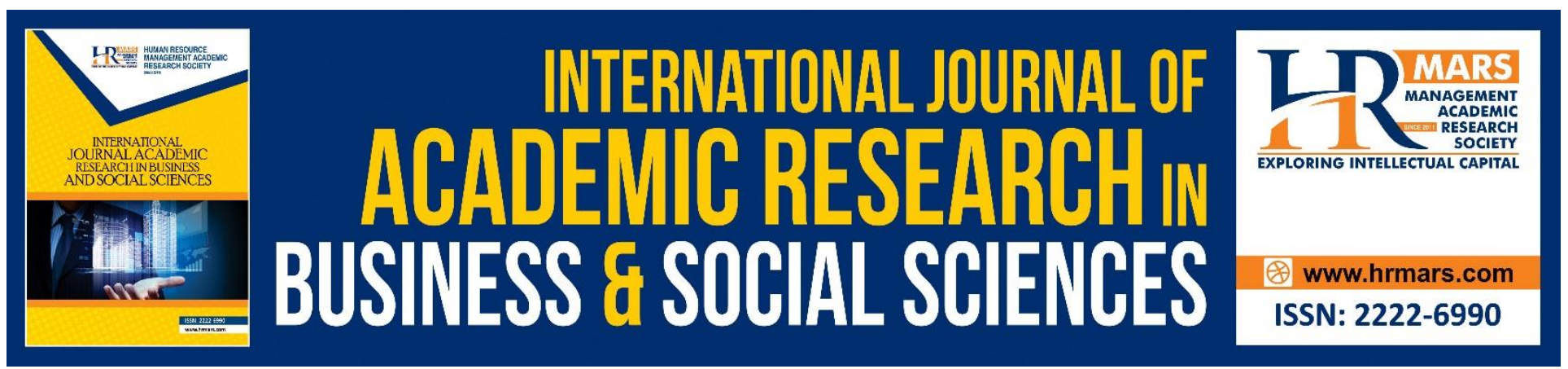

\section{Improvement in Sarf(Morphology) Competency through Gamification at Miri National Religious Secondary School (SMKAMi)}

${ }^{1}$ Suhaila Zailani, ${ }^{1}$ Kaseh Abu Bakar, ${ }^{2}$ Nik Farhan Mustapha, ${ }^{1}$ Hakim Zainal, ${ }^{3}$ Zulkifli Nawawi \& ${ }^{1}$ Ezad Azraai Jamsari

${ }^{1}$ Centre for The Middle East and Nusantara, Faculty of Islamic Studies, Universiti Kebangsaan Malaysia, 43600 UKM Bangi, Selangor, Malaysia

${ }^{2}$ Arabic Language Unit, Faculty of Modern Languages and Communication, Universiti Putra Malaysia, 43400 UPM Serdang, Selangor, Malaysia

${ }^{3}$ Arabic Language Program, Faculty of Islamic Studies, Universiti Kebangsaan Malaysia, 43600 UKM

Bangi, Selangor, Malaysia

*Corresponding Author: eajsti@gmail.com

\section{Abstract}

Learning through the gamification method can bring the students directly closer to real experience. Students have the opportunity to improve their ability to remember, increase sensitivity to interaction process and possess the capability to objectively analyse a situation. The purpose of this article is to introduce a type of gamification to strengthen Sarf (morphology), in addition to tracking improvement in Sarf competency after implementing the gamification method at Miri National Religious Secondary School (SMKAMi) in the 2017 Malaysian Certificate of Examination (SPM). This research uses a qualitative method and data was taken mainly from the Arabic Morphology Diagnostic Test (UDMA) and through the instrument of interview using WhatsApp application (voice message or voice recording). Two teachers were involved in the interview session: Head of Arabic Language Committee and an Arabic language teacher who teaches Form 5. The data obtained were transcribed in writing and descriptively analysed. Research findings show an improved achievement in Arabic language subject of the 2017 SPM by 1.09 with Average Grade of Subjects (GPMP) of 3.64 compared to 4.73 of the previous year. Research results show that the gamification method can resolve student weakness in Sarf, especially in remembering the verb and noun patterns and their derivatives, besides increasing student engagement, creating fun and fostering a positive attitude through game activity. The implications of this research will open the space for research on gamification designs appropriate for strengthening Nahu and Sarf with a high prospect for their application in the context of Arabic language education.

Keywords: Sarf (morphology), gamification, religious secondary school, Arabic teaching and learning 


\section{INTRODUCTION}

Various techniques are practised in teaching and learning Arabic education. Among the most interesting is language learning gamification because it creates an active and fun learning environment. al-Barry (2011) found that language learning gamification is effective for students learning basic Arabic language because students are more inclined towards something new and are motivated to constantly seek knowledge to satisfy their curiosity as compared to traditional teaching techniques. This statement is supported by Smith-Robbins (2010), Ibrahim and Teh (2015), and Mustari et al. (2012), that the gamification method is very effective to be applied in the teaching and learning of Arabic language.

Purely lecture-based language learning causes students to be fatigued and lose concentration. Hence, playing games in learning Arabic language stimulates student interest and motivates them to keep up their enthusiasm for gaining input. Studies related to the effect of gamification on student motivation have been identified (Furdu et al. 2017; Cahyani 2016; Ibrahim \& Teh 2015; Flores 2015; Godwin-Jones 2014; Hamari et al. 2014; Herzig et al. 2013; Mahmoud \& Tanni 2014; Lee \& Hammer 2011) and they show gamification as having a big impact on the teaching and learning process. The motivation element is very essential and is intertwined with learning theory. Without motivation, learning is meaningless and games created become difficult to adjust to other training methods (Juzeleniene et al. 2014).

The learning experience, through activities and training conducted, is intensely felt by students and practised as in the real world. This situation indirectly improves the psychomotor skills of students (Khaleel et al. 2016; Mostowfi et al. 2016; Fattah 2015; Hamizul \& Rahimi 2015; Mahmoud \& Tanni 2014; Lee \& Hammer 2011) and optimally stimulates their minds in completing given assignments creatively. The gamification approach also gives the opportunity and space for students to openly exhibit their talents and assess their own capabilities.

In addition, the concept of relaxed learning influences student psychology and positive behaviour. Language learning gamification enables reducing anxiety, encourages shy students to communicate and increases social skills as well as interpersonal skills (Ibrahim \& Teh 2015). The informal learning environment creates cooperation and the spirit of helping one another (Mostawfi et al. 2016; al-Barri 2011) in completing given group assignments.

\section{RESEARCH BACKGROUND}

\section{Statement of Problem}

The main weakness of students which causes failure to master Arabic language skills was identified in past studies, such as by Mezah (2006), Mezah \& Mohammad (2011), Sejo (2012), al-Khulufi (2015), and also Zailani and Ahmad (2015a; 2015b). Several studies have also shown that the game's approach is very effective in teaching and learning Arabic language (Mustapa et al., 2012; Mustari et al. 2012; Ibrahim \& The 2015; Omar \& Zailani 2016; Ahmad et al. 2016; Jasni et al. 2018; Zailani et al. 2016a; Zailani et al. 2016b). Beginning from the abovesaid studies, the purpose of this research is to assess any improvement in Nahu and Sarf competency based on the results of Arabic language 
INTERNATIONAL JOURNAL OF ACADEMIC RESEARCH IN BUSINESS AND SOCIAL SCIENCES

Vol. 9, No. 1, Jan, 2019, E-ISSN: 2222-6990 (C) 2019 HRMARS

subject in the 2017 SPM examination, after adopting the gamification approach in the learning of Nahu and Sarf.

\section{Research Objectives}

1. To introduce suitable types of gamification to be applied for strengthening Sarf.

2. To track improvement in Sarf competency at di SMKAMi after the implementation of gamification method.

\section{Research Methodology}

This research uses qualitative methods and the main data was collected from the Arabic Mporphology Diagnostic Test (UDMA) report dated 10 April 2017 sent to the school. The second data source for this research was obtained through interview instrument of teachers using WhatsApp application (voice message or voice recording). Two teachers are involved in interview sessions: the Head of the Arabic Language Committee and the other, an Arabic language teacher teaching Form 5. Data obtained and transcribed in writing is descriptively analysed based on 10 given questions. The response to the interview with the Head of Arabic Language Committee is coded G1 and for the Arabic language teacher coded G2.

\section{TASRIF GAME BOARD PROGRAM APPLICATION AT SMKAMi}

This program was implemented at SMKAMi on 6th February 2017. The participants were 115 students of Form 5 and Arabic language teachers of Form 4 and 5. Four UKM lecturers and another from UPM acted as facilitators for this program. Three types of board game board were used, as follows:

\section{Aplication of Tasrif Board}

A board game in the form of an A3-sized schedule, consisting of five tasrif in Arabic language, that is, Madi Verb, Mudari' Verb, doer noun, object noun and derived noun.

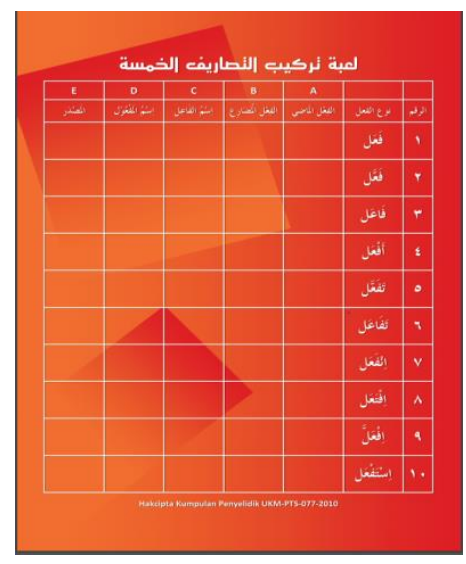

MY IPO APP NO: LY 2014001302

Advantage: This board game is used to solve the student's problem of lacking skill in five tasrif. 
INTERNATIONAL JOURNAL OF ACADEMIC RESEARCH IN BUSINESS AND SOCIAL SCIENCES

Vol. 9, No. 1, Jan, 2019, E-ISSN: 2222-6990 @ 2019 HRMARS

\section{Aplication of Mushtaqqat Board}

A board game in the form of an A3-sized schedule, consisiting of seven types of Arabic derived nouns, that is, doer noun, object noun, adjectival noun, hyperbolic noun, tool noun, comparative noun, place and time noun.

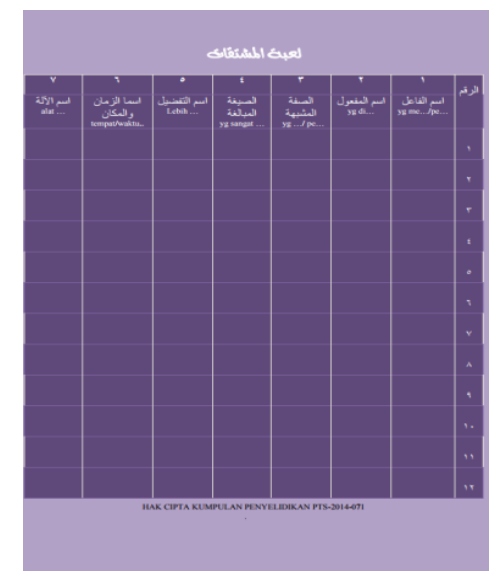

No. IP: UKM IKB/108/2/1176

Advantage: This board game is used to solve student's problem of lacking skill in differentiating types of derived nouns and their patterns. This game helps the student to remember Arabic derived noun patterns.

\section{Aplication of Tajrid al-Af'al Board}

The tajrid board game is used to help students identify the original letters and affixed letters for a verb. It comprises of four boards: three-letter verb with one affixed letter, three-letter verb with two affixed letters, three-letter verb with three affixed letters, and four-letter verb with one affixed letter and two affixed letters. On the left side, for each row of boxes is placed the required name or item. If students fill the boxes according to the required item, they will eventually discover the original word and affixed letter of a mazid verb.

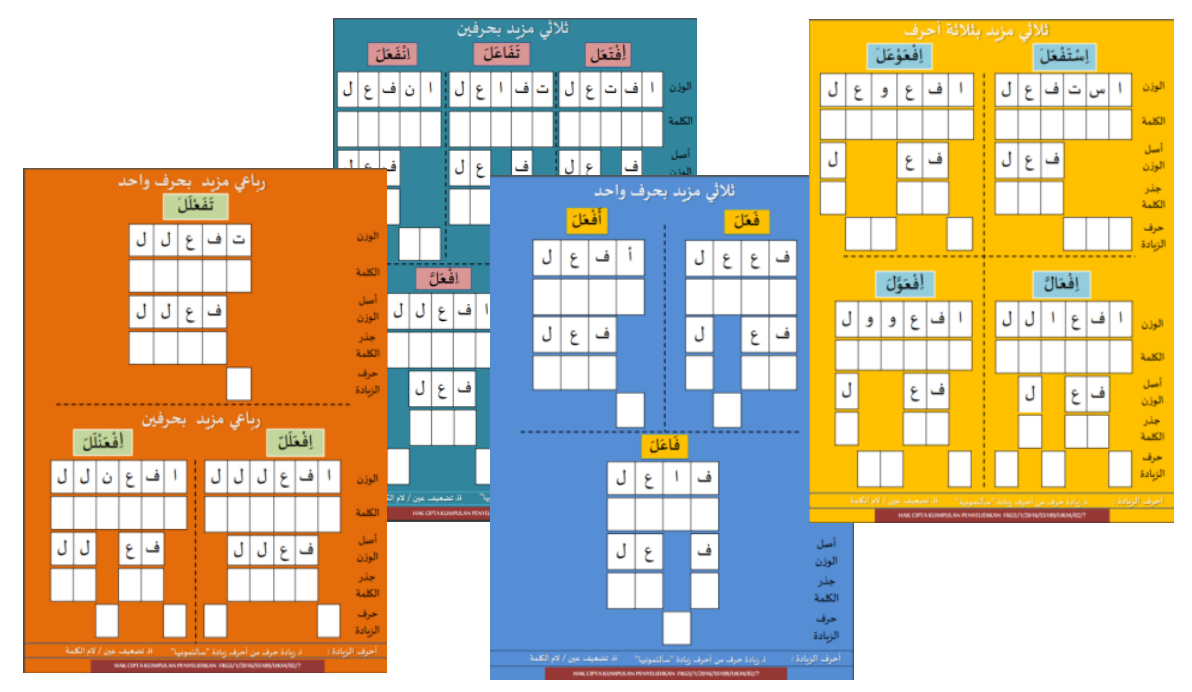


INTERNATIONAL JOURNAL OF ACADEMIC RESEARCH IN BUSINESS AND SOCIAL SCIENCES Vol. 9, No. 1, Jan, 2019, E-ISSN: 2222-6990 @ 2019 HRMARS

No. IP: UKM IKB/108/2/1528

Advantage: This game helps the students to differentiate between mujarrad verb and mazid verb as well as the derivatives, and to quickly identify the base/root word as well as distinguish the types of affixed verbs, whether one or two or three affixed letters.

\section{Aplication of Tajrid al-Mushtaqqat Board}

This board game is designed specially to trace the original letters and affixed letters for seven derived nouns based on a certain pattern. The game set comprises of nine boards, that is, two ism al-fa'il boards, two ism al-maf'ul boards, two sifat al-mushabbahah boards, one ism al-Alah board, one ism al-Tafdil and isma al-zaman wa al-makan board and one sighah al-mubalaghah board. On the left side for each row of boxes are placed required names/items. If students fill the boxes according to the required items, they will eventually discover the original word and affixed letters for each derived noun.

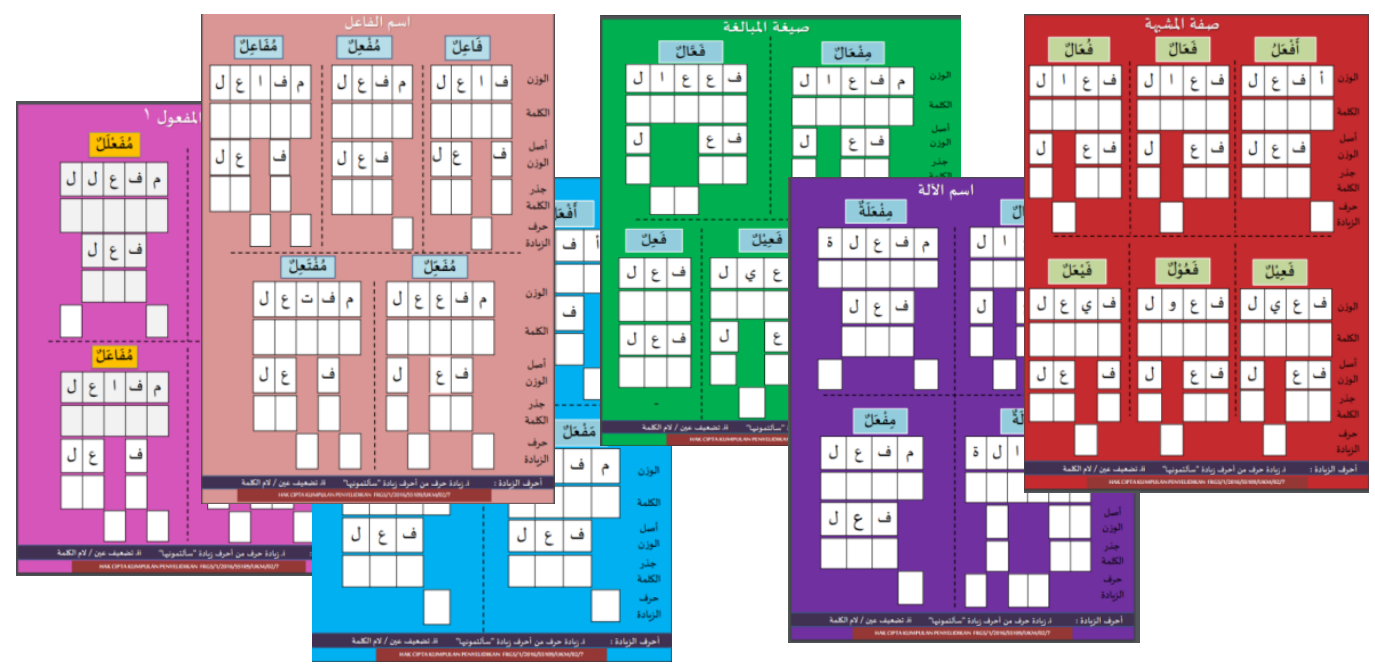

No. IP: UKM IKB/108/2/1874

Advantage: This board game helps students to quickly trace the root word and affixed letters for each derived noun, facilitates to guess the meaning of the words based on the root word as well as helps them to find the meaning of the words in the dictionary. The problem of difficulty in understanding the text is also reduced if students succeed in tracing the root word of a word.

TRACKING LEVEL OF SARF MASTERY THROUGH ARABIC MORPHOLOGY DIAGNOSTIC TEST (UDMA) A diagnostic test was conducted to track the competency or mastery level of Arabic Sarf (morphology) of Form 5 students at the selected school, SMKAMi. This test is an assessment procedure used to collect information on the students' shortcomings in learning, to identify the students' specific strengths and weaknesses, and identify their mastery of syllabus. The diagnostic test is forward- 
INTERNATIONAL JOURNAL OF ACADEMIC RESEARCH IN BUSINESS AND SOCIAL SCIENCES

Vol. 9, No. 1, Jan, 2019, E-ISSN: $2222-6990$ (c) 2019 HRMARS

looking because information from the test is used to set the direction for future teaching and learning. The research instrument used is the second set of the Arabic Morphology Diagnostic Test (UDMA) developed by a group of researchers under the scheme, FRGS/1/2016/SSI09/UKM/02/7, and registered as IP No.: UKM IKB/108/2/1533.

Table 1. Question Distribution in UDMA

\begin{tabular}{|c|l|c|}
\hline Section & \multicolumn{1}{|c|}{ Item } & $\begin{array}{c}\text { Number of Questions } \\
\text { (100) }\end{array}$ \\
\hline 1 & $\begin{array}{l}\text { Determination of verb tasrif } \\
\text { (conjugation) }\end{array}$ & 20 \\
\hline 2 & Additional Letters & 20 \\
\hline 3 & Affixation Patterns & 20 \\
\hline 4 & Use of Affixation Patterns in Sentence & 20 \\
\hline 5 & Derived Nouns & 20 \\
\hline
\end{tabular}

Table 2. Overall Results of Arabic Morphology Diagnostic Test (UDMA)

\begin{tabular}{|c|c|c|c|}
\hline Scale & Marks & No. of Students & Percentage (\%) \\
\hline Excellent & $80-100$ & 0 & 0 \\
\hline Good & $60-79$ & 25 & 22 \\
\hline Average & $40-59$ & 87 & 76 \\
\hline Weak & $20-39$ & 3 & 3 \\
\hline
\end{tabular}

Diagram 1. Results of UDMA at SMKAMi

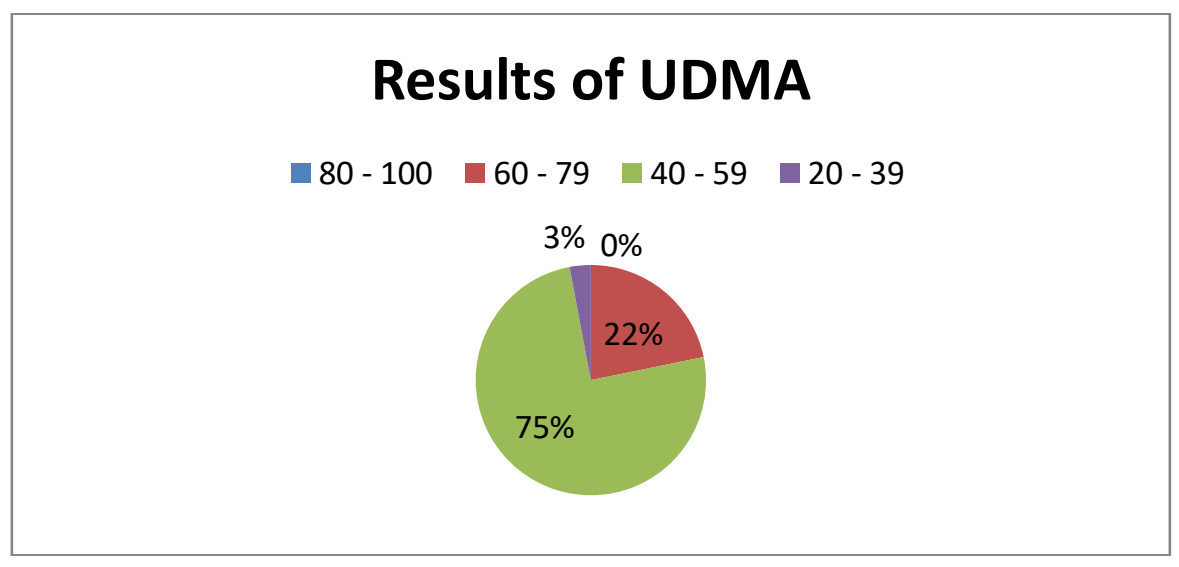

Table 2 above shows that not a single student scored excellent results, that is, achieving 80 - 100 marks. The majority of students, 87 persons, are at the average level of 40 - 59 marks and the rest, 26 students, are at a good level of $60-79$ marks and only 3 students at a weak level of 20-39 marks. On the whole, Form 5 students at SMKAMi are seen to be still at the average level in mastery of Sarf. 
INTERNATIONAL JOURNAL OF ACADEMIC RESEARCH IN BUSINESS AND SOCIAL SCIENCES Vol. 9, No. 1, Jan, 2019, E-ISSN: 2222-6990 @ 2019 HRMARS

Table 3. Results of Arabic Morphology Diagnostic Test (UDMA) according to Section

\begin{tabular}{|c|c|c|c|c|c|c|}
\hline \multirow{2}{*}{ Scale } & \multirow{2}{*}{ Marks } & \multicolumn{5}{|c|}{ No. of Students } \\
\cline { 3 - 7 } & & Section 1 & Section 2 & Section 3 & Section 4 & Section 5 \\
\hline Excellent & $16-20$ & 4 & 29 & 72 & 0 & 1 \\
\hline Good & $11-15$ & 45 & 61 & 42 & 5 & 13 \\
\hline Average & $6-10$ & 59 & 21 & 1 & 68 & 69 \\
\hline Weak & $1-5$ & 7 & 4 & 0 & 42 & 32 \\
\hline
\end{tabular}

Table 3 above shows the aspects which are less than satisfactorily mastered by SPM 2017 candidates at SMKAMi as tracked by the Arabic Morphology Diagnostic Test (UDMA). The students failed to answer well in two sections of the test, sections 4 on Affixiation Patterns in Sentences and Section 5 on Derived Nouns. As for Section 1 on Determination of Verb Tasrif (Conjugation), more than half of the students failed to master it well.

\section{IMPROVEMENT IN SARF COMPETENCY THROUGH GAMIFICATION METHOD}

From the results of the Diagnostic Test (UDMA), the school, SMKAMi, and Arabic language teachers, specifically know the level of Sarf mastery among the 2017 SPM candidates. This helps the teachers to plan a strategy and suitable teaching method to apply to the students, especially in giving special focus on aspects or topics less than satisfactorily mastered by students. Among the efforts and approaches is the gamification approach and frequent drilling to help students improve their mastery in certain topics. The following are the responses to interview questions related to gamification approach:

1. What is your view of the gamification approach in teaching and learning Arabic language, specifically in Sarf (Morphology) introduced by UKM?

G1-In my view, the gamification approach for the sarf topic is very good and effective because it helps students understand the wazan technique of words in a simple way.
G2- In my view, the gamification of Sarf introduced by UKM is very helpful to facilitate students' understanding of Sarf.

2. In your view, does the Tasrif game Board Application Program give a positive impact on the teaching method of Arabic language teacher?

G1- We use various methods of teaching Arabic language and the Tasrif game board is one of the methods we apply especially in the Sarf Section and the impact obtained from the test/training is positive.
G2- Yes. The tasrif game board application program introduced really gives a positive impact to teaching Arabic language by the teachers at SMKAMi in diversifying teaching techniques. 
3. Has the students' perception of Arabic language subject, especially in learning Sarf, changed after following the program?

G1- Good students are able to quickly understand the topic Sarf, average students are able to wazan the words after having been given explanation, weak students are able to do exercises after guidance.
G2- Students say that the tasrif board game application makes it easier for them to understand Sarf, especially for the topic wazan.

4. What is the main strategy implemented to improve Arabic language skills, especially Sarf, among Form 5 students?

G1- Repeated exercises.
G2- Some of the main strategies we carry out to improve student performance in Arabic language subject is by holding the Young Murshid (Teacher/Guide) Program, Additional classes for GALUS (students who sometimes fail and need to be helped to pass) and CEMERLANG (good or excellent) students, Games and Centred Drill Training.

5. If the gamification approach is implemented, explain in what form the games are implemented?

G1- Tasrif Board for Sarf, rubrics for Nahu (Grammar) and Scrabble for vocabulary.
G2- Sentence rubrics, tasrif board and Arabic scrabble.

6. How is the approach implemented, individually or in groups, as a teaching aid in class or out of class activity, relaxed activity or competition?

G1- In groups of four.Conducted out of class when all Form 5 students are combined in one G2- The said activity is done in class in groups. class. Usually during teaching and learning.

7. How frequent is the games method implemented in a week/month?

G1- It is implemented when teaching the topic Sarf relating to wazan and fi'l mazid.
G2 - The game activity is implemented only once a week for each class and then resumed frequently, after the teaching syllabus is completed, for the purpose of strengthening. 
Based on the answers in interviews with the Head of the Arabic language Committee and the Arabic language teacher SMKAMi, they both agreed that the Game Board Application Program implemented by UKM has a positive impact on teachers especially in diversifying teaching techniques. Students also hold a good perception and give a good response towards implementation of the game method in learning Sarf. They are able to understand the topic wazan and technique of finding the wazan of words more quickly. Some of the strategies implemented at SMKAMi in order to improve Arabic language skills, especially Sarf, are through methods of playing games, centred training drill and repetition. This approach is implemented in groups in class or outside of teaching and learning time. This method is also implemented while teaching Sarf topics relating to wazan and fi'l mazid and is frequently implemented after the completion of the syllabus for the purpose of strengthening of topics not well mastered by students.

\section{IMPROVEMENT IN ARABIC LANGUAGE ACHIEVEMENT IN 2017 SPM OF SMKAMi}

Improvement in Arabic language achievement among students of SMKAMi may be clearly seen in the answers $\mathrm{G} 1$ and $\mathrm{G} 2$ to interview questions 8 and 9, as follows:

8. How is the performance or achievement in Arabic language of Form 5 students in 2017 SPM?

G1- Our performance in 2017 SPM is very good and has improved from the previous years Alhamdulillah we achieved $100 \%$ pass in Arabic language for 118 candidates (GPMP: 3.64)
G2- Student performance in 2017 SPM shows a very good improvement by obtaining results GPS: 3.64 and is recognised as the best subject at the Sarawak state level.

9. What is the rate of improvement in Arabic language achievement in the 2017 SPM compared to the previous years?

G1- The rate of improvement is very significant because in the previous years the GPMP of Arabic language for this school was the figure 4 or 5. This year we broke record after achieving the figure 3.
G2- The rate of improvement for the 2017 Arabic language results is 1.09 compared to the 2016 results whereby GPMP: 4.73.

Based on the above answers, the improvement in Arabic language subject achievement in the 2017 SPM at SMKAMi is very encouraging. The rate of improvement was 1.09 in the year 2017 with Subject Grade Average (GPMP) of 3.64 compared to GPMP: 4.73 in the year 2016 . With a $100 \%$ pass of 118 candidates in the Arabic language subject, SMKAMi is recognized as the best school for the Arabic language subject at the state level of Sarawak. 


\section{IMPACT OF TASRIF GAME BOARD APPLICATION PROGRAM}

1. The level of student mastery in a subject may be tracked through a diagnostic test. As an example, the level of student mastery of Arabic language morphology is successfully tracked by the Arabic Morphology Diagnostic Test (UDMA).

2. A diagnostic test to detect aspects or topics which students fail to master satisfactorily needs to be done by the school or another study centre in order to help teachers to plan suitable teaching and learning methods and strategy in addition to giving more focus on the aspects and topics.

3. To give new ideas on developing teaching aids based on game boards to schools and Arabic language teachers. This game method is very suitable to be practised as one of the learning methods for the $21^{\text {st }}$ Century.

4. The game method or gamification enables improvement Sarf competency among students if implemented in a scheduled manner and continuously whether in the class or outside of teaching and learning time.

\section{CONCLUSION}

Research findings show that gamification can help to solve student weakness in Nahu and Sarf especially in remembering verb and noun patterns and their derivatives, in addition to increasing student engagement, creating fun and fostering positive attitude and healthy competition through game activities. The implications of this research are to pave the way for studies on suitable gamification designs to strengthen Sarf with a high prospect of application in Arabic language education. Gamification applications can become a teaching activity and practical and interactive teaching aid compatible with the Malaysian Ministry of Education's aspiration toward creating a $21^{\text {st }}$ Century learning environment through a new approach and strategy so that each student has the ability to possess and master the required skills in the $21^{\text {st }}$ Century.

\section{ACKNOWLEDGEMENT}

This study is financed by the research grant of FRGS/1/2016/SS109/UKM/02/7, the Ministry of Education Malaysia and Universiti Kebangsaan Malaysia (UKM, The National University of Malaysia).

\section{REFERENCES}

Ahmad, S., Zailani, S. \& Zainal, H. (2016). Dawr al-mu'allimin fi ta'ziz al-lughah al-Arabiyyah li tulab Qism al-Dirasat al-'Arabiyyah wa al-Hadarah al-Islamiyyah. Prosiding Seminar Antarabangsa Pengajaran Bahasa dan Sastera Arab kepada Penutur Bukan Arab (ICONTALL 2016), pp. 409-414.

al-Barri, Qasim. (2011). Athar istikhdam al-al'ab al-lughawiyah fi minhaj al-lughah al-'Arabiyyah fi tanmiyyat al-anmat al-lughawiyah lada talabat al-marhalah al-asasiyyah. Majallat al-Urduniyah fi al'Ulum al-Tarbawiyyah, 7, 23-34.

al-Khulufi, Fatimah. (2015). Athar al-wa'y al-sarfi fi ta'allum al-qira'ah. al-Tadris: Majallat Kulliyyat 'Ulum al-Tarbiyyah, 7, 39-45.

Cahyani, A.D. (2016). Gamification approach to enhance students engagement in studying language 
INTERNATIONAL JOURNAL OF ACADEMIC RESEARCH IN BUSINESS AND SOCIAL SCIENCES

Vol. 9, No. 1, Jan, 2019, E-ISSN: 2222-6990 C 2019 HRMARS

course. MATEC Web of Conferences, 58, 03006.

Fattah, S.F.E.S.A. (2015). The effectiveness of using whatsapp messenger as one of mobile learning techniques to develop students' writing skills. Journal of Education and Practice, 6(32), 115-127.

Flores, J.F.F. (2015). Using gamification to enhance second language learning. Digital Education Review, 27-June, 32-54.

Furdu, I., Tomozei, C. \& Kose, U. (2017). Pros and cons of gamification and gaming in classroom. BRAIN Broad Research in Artificial Intelligence and Neuroscience, 8(2), 56-62.

Godwin-Jones, R. (2014). Games in language learning: Opportunities and challenges. Language Learning \& Technology, 18(182), 9-19.

Hamari, J., Koivisto, J. \& Sarsa, H. (2014). Does gamification work? A literature review of empirical studies on gamification. Proceedings of the Annual Hawaii International Conference on System Sciences, pp. 3025-3034.

Hamizul, M. \& Rahimi, N.M. (2015). Design and development of Arabic online games: A conceptual paper. Procedia Social and Behavioral Sciences, 174, 1428-1433.

Herzig, P., Jugel, K., Momm, C., Ameling, M. \& Schill, A. (2013). GaML - A modeling language for gamification. Proceedings 2013 IEEE/ACM 6th International Conference on Utility and Cloud Computing, UCC 2013, pp. 494-499.

Ibrahim, F. \& The, K.S.M. (2015). Pengaruh permainan bahasa terhadap motivasi murid sekolah rendah dalam pembelajaran perbendaharaan kata bahasa Arab [The influence of language games on motivation of primary school pupils in learning Arabic vocabulary]. Tinta Artikulasi Membina Ummah, $1(2), 41-50$.

Jasni, S.R., Zailani, S. \& Zainal, H. (2018). Pendekatan gamifikasi dalam pembelajaran bahasa Arab. Paper presented Seminar Fatwa, Pengajian Pendidikan dan Inovasi Islam Antarabangsa. Organised by Institut Pengurusan dan Penyelidikan Fatwa Sedunia (INFAD), Universiti Sains Islam Malaysia. Bandar Baru Nilai, Negeri Sembilan, 28-29 August.

Juzeleniene, S., Mikelioniene, J., Escudeiro, P. \& Carvalho, C.V. de. (2014). GABALL project: Serious games based language learning. Procedia Social and Behavioral Sciences, 136, 350-354.

Khaleel, F.L., Sahari @ Ashaari, N., Tengku Wook, T.S.M. \& Ismail, A. (2016). Gamification elements for learning applications. International Journal on Advanced Science, Engineering and Information Technology, 6(6), 868-874. 
INTERNATIONAL JOURNAL OF ACADEMIC RESEARCH IN BUSINESS AND SOCIAL SCIENCES

Vol. 9, No. 1, Jan, 2019, E-ISSN: 2222-6990 (C) 2019 HRMARS

Lee, J. \& Hammer, J. (2011). Gamification in education: What, how, why bother?. Academic Exchange Quarterly, 15(2), 1-5.

Mahmoud, A.A.A. \& Tanni, Z.A. (2014). Using games to promote students' motivation towards learning English. Al-Quds Open University Journal for Educational \& Psychological Research Studies, 2(5), 11-33.

Mezah, C.R. \& Mohammad, N. (2011). Pengajaran \& Pembelajaran Kosa Kata Arab. Serdang: Penerbit Universiti Putra Malaysia.

Mezah, C.R. (2006). Kesilapan Leksikal dalam Pembelajaran Bahasa Arab [Lexical Mistakes in Learning of Arabic Language]. Serdang: Universiti Putra Malaysia Press.

Mostowfi, S., Mamaghani, N.K. \& Khorramar, M. (2016). Designing playful learning by using educational board game for children in the age range of 7-12 (A case study: Recycling and waste separation education board game). International Journal of Environmental and Science Education, 11(12), 5453-5476.

Mustapa, A.M., Rahman, A.A., Mohamed, F.A., Kadir, K., Osman, K. \& Ismail, Z. (2012). Peningkatan kemahiran bahasa Arab melalui modul permainan bahasa. Prosiding Seminar Pemantauan Projek Penyelidikan Tindakan/Strategik (PTS) Fakulti Pengajian Islam, pp. 1-6.

Mustari, M.I., Jasmi, K.A., Muhammad, A., Bakar, R.A. \& Ahamad, S. (2012). Permainan bahasa dalam pengajaran dan pembelajaran bahasa Arab [Language games in teaching and learning Arabic language]. Proceedings of Seminar Antarabangsa Perguruan dan Pendidikan Islam [SEAPPI2012], pp. 879-888.

Omar, T.N.A.T. \& Zailani, S. (2016). Aplikasi papan permainan al-mushtaqqat dalam Kursus PPPJ1143 Perkamusan Arab. Prosiding Seminar Antarabangsa Pengajaran Bahasa dan Sastera Arab kepada Penutur Bukan Arab (ICONTALL 2016), pp. 237-241.

Sejo, M.Z. (2012). Penekanan ilmu morfologi dalam buku teks bahasa Arab kurikulum baru sekolah menengah [Emphasis on morphology in textbooks of new Arabic language curriculum of secondary schools. Prosiding Persidangan Kebangsaan Pengajaran dan Pembelajaran bahasa Arab 2012, pp. 190-205.

Smith-Robbins, S. (2011). This game sucks: How to improve the gamification of education. EDUCAUSE Review, 46(1), 58-59.

Zailani, S. \& Ahmad, S. (2015a). Konsep 3T dalam peta minda al-mushtaqqat. Prosiding Seminar Pengajaran Bahasa, Kesusasteraan dan Kebudayaan Arab di Institusi Pengajian Tinggi Malaysia Peringkat Kebangsaan, pp. 26-40. 
INTERNATIONAL JOURNAL OF ACADEMIC RESEARCH IN BUSINESS AND SOCIAL SCIENCES

Vol. 9, No. 1, Jan, 2019, E-ISSN: 2222-6990 C 2019 HRMARS

Zailani, S. \& Ahmad, S. (2015b). Pengetahuan awal tentang ilmu al-ishtiqaq dalam kalangan pelajar siswazah Fakulti Pengajian Islam, UKM. Prosiding Pengajaran dan Pembelajaran Bahasa dan Sastera Arab Malaysia-Indonesia, pp. 195-212.

Zailani, S., Ahmad, S. \& Zainal, H. (2016a). Aplikasi papan permainan al-mushtaqqat. Poster K-Novasi P\&P UKM 2016. Universiti Kebangsaan Malaysia, Bangi.

Zailani, S., Ahmad, S., Zainal, H. \& Bakar, K.A. (2016b). Istikhdam al-al'ab al-ta'limiyyah fi tanmiyyat al-maharat al-sarfiyyah. Prosiding Seminar Antarabangsa Pengajaran Bahasa dan Sastera Arab kepada Penutur Bukan Arab (ICONTALL 2016), pp. 301-306. 